\title{
PENGEMBANGAN MEDIA BIYAS MATA PELAJARAN IPA KELAS V DI SEKOLAH DASAR
}

\author{
Erika Nuril Izza ${ }^{1}$, Arfilia Wijayanti ${ }^{2}$ \\ ${ }^{1,2}$ Program Studi Pendidikan Guru Sekolah Dasar \\ Fakultas Ilmu Pendidikan Universitas PGRI Semarang \\ 'Erikanuril@gmail.com
}

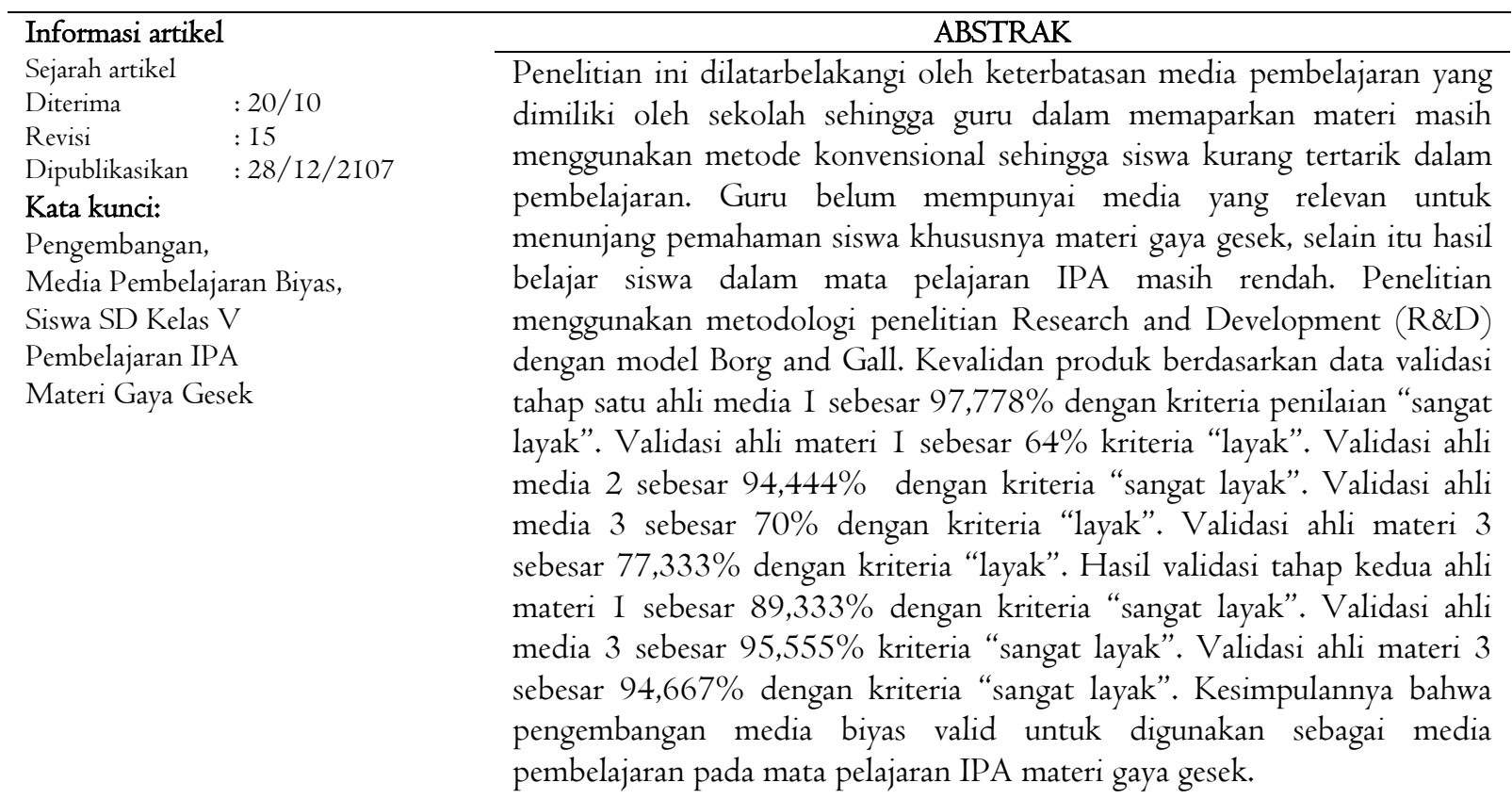

Key word:

Development,

Biyas Learning Media,

fifth Grade Elementary Student

Science Lesson

Material of Swipe Style

\section{ABSTRACT}

This research is motivated by the limitations of instructional media owned by school. The teacher explained the material still use conventional methods so that the students are less interested in the learning process. The Teacher does not have the relevant media to support students 'understanding, especially in friction force material. I $n$ addition outcomes of the student's in science subjects is still low. This Research used Research and Development ( $\&$ \& ) research of methodology with Borg and Gall's model development procedures. The validity of the product based on one-stage validation data of one media expert I is $97.778 \%$ with the criteria of assessment is "very feasible". The Expert material validation I is $64 \%$ with the criteria "eligible". Validation of media expert 2 is $94,444 \%$ with criterion "very feasible". Validation of media expert 3 is $70 \%$ with "decent" criterion. The Material 3 validation is $77.333 \%$ with "feasible" criteria. The result of the second stage validation of material expert I is $89.333 \%$ with the criteria "very feasible". The Expert 3 media validation of $95.555 \%$ "very feasible" criteria. Material expert validation 3 is $94,667 \%$ with criteria "very feasible". The conclusion of the research is the development of biyas media is valid to be used as a medium of learning on science subjects friction material. 


\section{Pendahuluan}

Kegiatan pembelajaran tidak dapat lepas dari media yang merupakan sarana untuk mencapai tujuan pembelajaran. Menurut Susilana dan Riyana (2009: 7) media merupakan wadah dari pesan. Sedangkan Arsyad (2016: 3) mengungkapkan bahwa media adalah alat-alat yang menyampaikan atau mengantarkan pesan-pesan pembelajaran. Jadi dapat disimpulkan bahwa untuk mendapatkan pembelajaran yang baik dengan pesan-pesan dalam pembelajaran tersebut tersampaikan dengan maksimal maka diperlukan media yang baik juga.

Berdasarkan hasil observasi di SD Negeri Pedurungan Kidul 02 Semarang, permasalahan pertama yang dihadapi adalah keterbatasan media pembelajaran di sekolah sehingga guru dalam memaparkan materi masih menggunakan metode konvensional dan hanya menggunakan buku acuan dengan siswa lebih sering mencatat materi kemudian mengerjakan soal. Hal tersebut membuat siswa kurang tertarik dalam pembelajaran. Permasalahan yang kedua, guru belum mempunyai media relevan untuk menunjang pamahaman siswa mata pelajaran Ilmu Pengetahuan Alam (IPA) khususnya materi gaya gesek karena selama ini materi gaya gesek hanya disampaikan dengan cara ceramah saja. Permasalahan yang ketiga, hasil belajar siswa dalam mata pelajaran Ilmu Pengetahuan Alam (IPA) yang masih rendah dan kurang dari KKM 70, hal ini berdasarkan nilai ulangan harian siswa yang berjumlah 38 dengan 16 siswa tuntas sedangkan 22 siswa belum tuntas. Jadi ketuntasannya mencapai $42 \%$ dan ketidaktuntasan mencapai $58 \%$. Berdasarkan latar belakang tersebut maka rumusan masalah penelitian ini adalah Bagaimanakah Kevalidan Pengembangan Media Biyas (Bidang Gaya Gesek) pada Mata Pelajaran IPA Kelas V di SD ?. Tujuan penelitiannya adalah mengembangkan media biyas yang valid pada mata pelajaran IPA kelas $\mathrm{VSD}$.

\section{Metode Penelitian}

Jenis penelitian yang digunakan yaitu penelitian dan pengembangan. Metode penelitian dan pengembangan atau dalam bahasa inggrisnya Research and Development adalah metode penelitian yang digunakan untuk menghasilkan produk tertentu, dan menguji keefektifan produk tersebut (Sugiyono 2010: 297). Model yang digunakan dalam penelitian ini adalah model Borg and Gall yang mempunyai I0 langkah (Sugiyono, 20I5: 35-36). Namun hanya sampai pada tahap kelima yaitu

\section{Research and information}

Mengumpulkan informasi kajian pustaka dan pengamatan kelas

\section{Planning}

Mengidentifikasi kebutuhan siswa seperti merumuskan tujuan pengembangan,identifikasi standar kompetensi dan kompetensi dasar, menyusun sintaks media

\section{Develop Preliminary from of Product}

Pengembangan bentuk produk awal mencakup penyiapan materi pembelajaran, buku pegangan dan alat-alat evaluasi

\section{Preliminary Field Testing}

Uji coba disekolah, pengumpulan data dengan wawancara, observasi, kuesioner. Hasilnya selanjutnya dianalisis.

\section{Main Product Revision.}

Melakukan revisi utama terhadap produk didasarkan pada saran-saran pada uji coba.

Studi pendahuluan dilakukan di SDN Pedurungan Kidul 02 Semarang pada bulan Desember 2016. Pengolahan data diambil dari validasi dan ahli materi. Teknik pengumpulan data berupa observasi, 
wawancara dan kuesioner. Instrumen yang digunakan berupa angket. Teknik analisis data, yaitu analisis deskriptif kualitatif dan analisis deskriptif kuantitatif. Data kualitatif diperoleh dari hasil pengisian lembar penilaian para ahli dengan acuan skala likert berisi 5 skala, yaitu:

Sangat Baik (SB) dengan skor 5

Baik (B) dengan skor 4

Cukup (C) dengan skor 3

Kurang $(\mathrm{K})$ dengan skor 2

Sangat Kurang (SK) dengan skor I

Digunakan rumus sebagai berikut untuk menghitung persentase angka:

$$
\text { Persentase (\%): } \frac{\text { Skor total }}{\text { Skor maximum }} \times 100 \%
$$

Dari persentase yang telah diperoleh kemudian dipindahkan ke dalam kalimat yang bersifat kualitatif. Menentukan kriteria dilakukan dengan cara seperti tabel dibawah ini dalam tabel range persentase dan kriteria kualitatif program.

Tabel I. Range Persentase dan Kriteria Program

\begin{tabular}{ll}
\hline Penilaian & Kriteria Interpretasi \\
\hline $81 \%-100 \%$ & Sangat Layak \\
$61 \%-80 \%$ & Layak \\
$41 \%-60 \%$ & Cukup Layak \\
$21 \%-40 \%$ & Tidak Layak \\
$0 \%-20 \%$ & Sangat Tidak Layak \\
\hline
\end{tabular}

\section{Hasil dan Pembahasan}

\section{Deskripsi Hasil Pengembangan}

Media biyas merupakan singkatan dari media bidang gaya gesek untuk mata pelajaran IPA materi gaya gesek. Media biyas merupakan media tiga dimensi yang terbuat dari bahan kayu berbentuk koper yang tahan lama dan dapat disimpan. Media biyas terdapat bidang gaya gesek berupa tiga lintasan yang bertekstur licin dan kasar. Media biyas berbentuk tiga dimensi termasuk dalam golongan mock-up yaitu alat tiruan sederhana dari benda sebenarnya dimana sengaja dipilih bagian-bagian yang memang penting dan yang diperlukan saja untuk dibuat sesederhana mungkin supaya mudah dipelajari (Sanaky, 20I3: I32). Media ini digunakan dengan cara percobaan dan diskusi sehingga siswa dapat aktif belajar. Media biyas telah di validasi oleh ahli materi dan ahli media serta sudah dibuat sesuai dengan kebutuhan siswa dan guru. Sebelum membuat media biyas peneliti melakukan wawancara terhadap guru dan menyebar angket kebutuhan siswa sehingga peneliti mengerti media yang diharapkan serta dibutuhkan oleh guru dan siswa. Berikut adalah produk dari media biyas: 


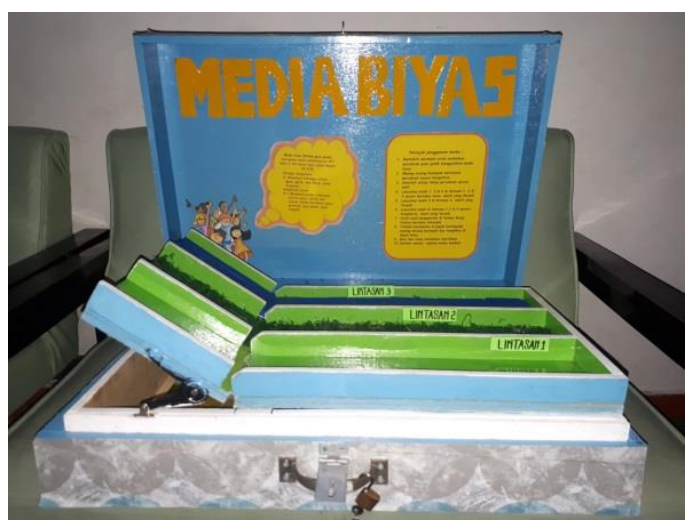

Gambar I. Media Biyas

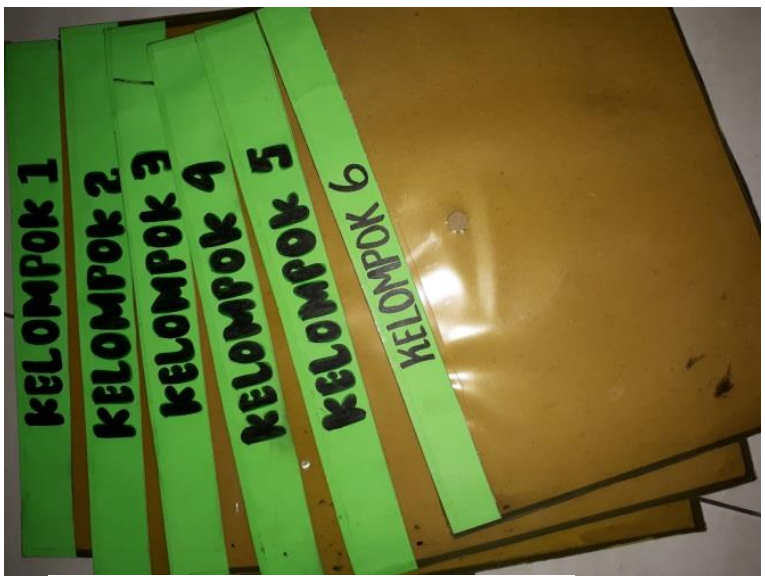

Gambar 3. Papan Kelompok

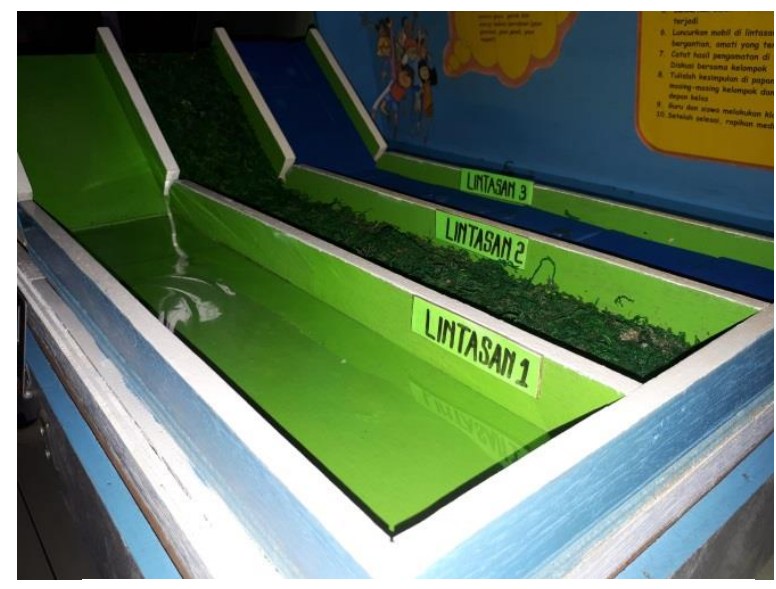

Gambar 2. Lintasan dalam Media Biyas

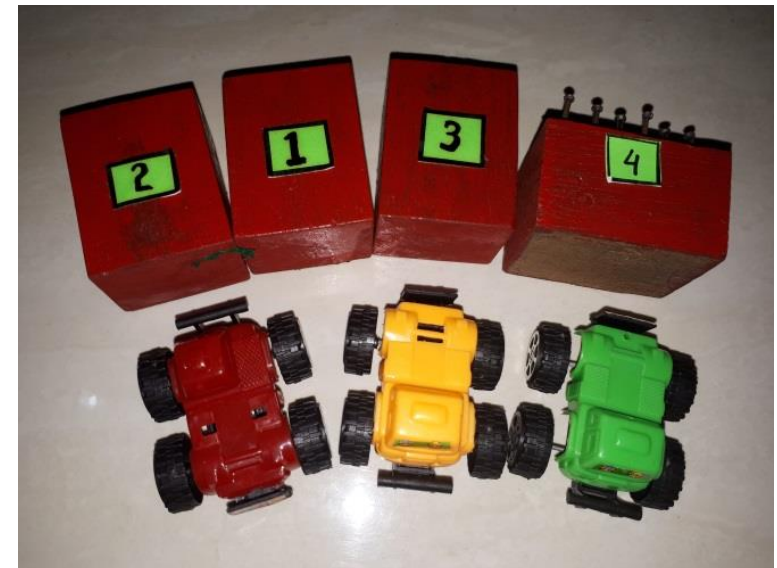

Gambar 4. Benda-benda untuk Percobaan

\section{Kevalidan Media Biyas}

Kevalidan media biyas diperoleh dari hasil validasi ahli media dan ahli materi dengan dua tahap validasi. Tiga validator dari penelitian ini yaitu validator satu sebagai ahli media dan materi, validator dua sebagai ahli media dan validator tiga sebagai ahli media dan ahli materi. Hasil validasi tahap pertama sebagai berikut:

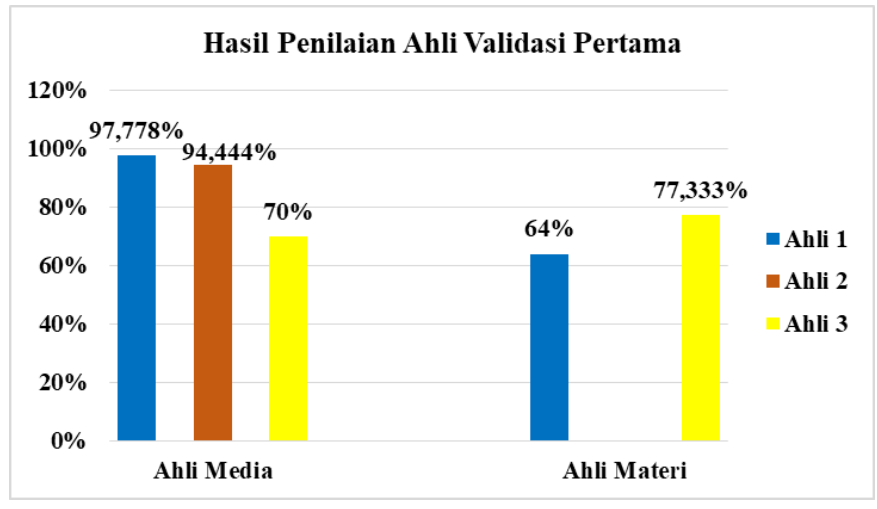

Gambar 5. Diagram Hasil Penilaian ahli Validasi Pertama 
Validasi media ahli satu memperoleh 97,778\% kriteria sangat layak digunakan, ahli dua memperoleh 94,444\% kriteria sangat layak dan ahli tiga 70\% kriteria layak digunakan. Validasi materi ahli satu memperoleh 64\% kriteria layak digunakan, ahli tiga memperoleh 77,333\% kriteria layak digunakan. Hasil validasi pertama masih terdapat revisi oleh ahli satu untuk revisi materi, ahli tiga untuk revisi media dan materi maka setelah direvisi dilanjutkan dengan validasi kedua sebagai berikut:

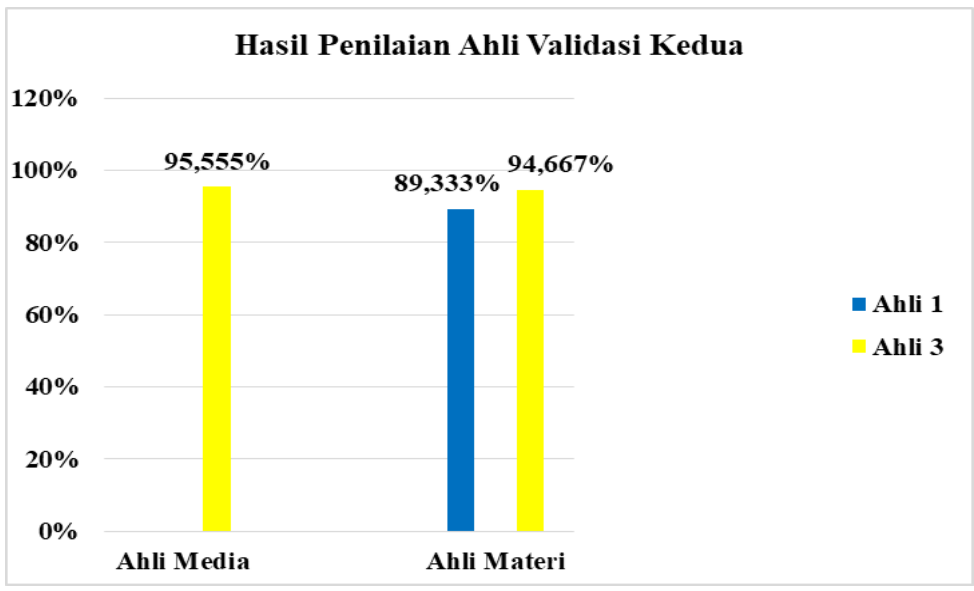

Gambar 6. Diagram Hasil

Penilaian ahli Validasi kedua

Validasi media ahli tiga memperoleh 95,555\% kriteria sangat layak digunakan, validasi materi ahli satu memperoleh 89,333\% kriteria sangat layak dan ahli tiga 94,667\% kriteria layak digunakan. Penilaian Media oleh guru kelas V diperoleh hasil 86,667\% dan penilaian materi oleh guru kelas V sebesar 88\%. Hasil tersebut menyimpulkan bahwa media media biyas telah valid dan sangat layak untuk digunakan.

\section{Kesimpulan}

Penelitian dan pengembangan ini menghasilkan produk berupa media biyas (bidang gaya gesek) pada mata pelajaran IPA kelas V SD. Kualitas produk termasuk kriteria "sangat layak" dengan rata-rata persentase 93,6II\% untuk media dari hasil validasi dosen ahli media dan penilaian media oleh guru kelas V. Kriteria "sangat layak" dengan rata-rata persentase 90,667\% untuk materi dari hasil validasi dosen ahli materi serta penilaian materioleh guru kelas V. Maka dinyatakan bahwa media biyas adalah media yang valid.

Berdasarkan data yang telah disebutkan maka pengembangan media biyas telah valid untuk digunakan sebagai media pembelajaran pada mata pelajaran Ilmu Pengetahuan Alam (IPA) materi gaya gesek.

Media biyas merupakan media yang dapat menarik perhatian siswa. Kegiatan percobaan dalam media biyas membuat siswa lebih banyak melakukan kegiatan sehingga pembelajaran menjadi menyenangkan dengan demikian sesuai dengan pendapat Sanaky (2013: 42) bahwa manfaat yang diperoleh dari penggunaan media pembelajaran yaitu lebih menarik perhatian, pembelajaran dapat bervariasi, menyenangkan dan tidak membosankan dan pembelajaran banyak melakukan kegiatan.

Media biyas merupakan media tiga dimensi yang valid dan layak digunakan sesuai dengan penelitian Septi Kiswandari dalam jurnal Pendidikan Guru Sekolah Dasar dimana penelitian tersebut menggunakan media diorama yang termasuk dalam golongan media tiga dimensi, menyatakan bahwa pengembangan media pembelajaran diorama daur air mata pelajaran IPA Kelas V layak digunakan dengan skor akhir uji kelayakan media 3,88 kategori sangat baik dari ahli media, skor 4,2I kategori sangat baik dari ahli materi.

Berdasarkan hasil tersebut penelitian ini masih mempunyai kelemahan yaitu Pembuatan media pembelajaran memerlukan biaya untuk proses produksinya. 
Harapan dari penelitian ini adalah guru dapat menggunakan media biyas untuk membantu pembelajaran efektif dan menyenangkan serta dapat mengembangkan media pembelajaran tiga dimensi golongan mock-up pada mata pelajaran dan materi lain

\section{Referensi}

Arsyad, A. (2016). Media Pembelajaran. Jakarta: Rajawali Pers.

Kiswandari, S. (2016). Pengembangan Media Pembelajaran Diorama Daur Air pada Mata Pelajaran IPA Kelas V SD. Jurnal Pendidikan Guru Sekolah Dasar, 970-975.

Sanaky, D. (2013). Media Pembelajaran Interaktif-Inovatif. Yogyakarta: Kakauba Dipantara.

Sugiyono. (2015). Metode Penelitian \& Pengembangan. Bandung: Alfabeta.

Susilana, R., \& Riyana, C. (2009). Media Pembelajaran. Bandung: Cv Wacana Prima.

Zubaidi, A., \& Lidyawati, R. (20I4). Penggunaan Media Pembelajaran Tiga Dimensi untuk Meningkatkan Hasil Belajar Matematika pada Siswa Kelas V SDN I Alas Tengah Situbondo. Jurnal Online Universitas Abdurachman Saleh Situbondo, I-I3. 